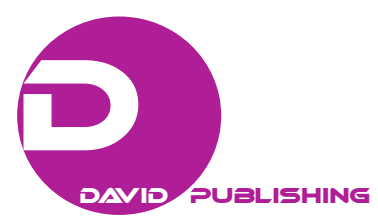

\title{
Corporate Governance, Banks Performance and Bank Crisis in Nigeria
}

\author{
Babatunde Afolabi, Awoyemi Olanike Bosede, Atsuwa Ruth, Akomolafe John Kehinde \\ Afe Babalola University, Ado Ekiti, Nigeria
}

\begin{abstract}
The study examined the relationship between corporate governance, bank performance and bank crisis in Nigeria. Corporate governance is the manner and ways in which the activities of an organisation are managed and controlled. Despite the implementation of corporate governance in Nigeria, monitoring and the much talk about consolidation exercise, weak corporate governance is still a big challenge in Nigerian banking system hence, the need to investigate the basic reasons for weak governance and ways of curbing them for a better financial system. The proxy for corporate governance employed in this study is the board of directors. Two vectors are selected for this research, as independent variables are Board size and Board composition. Whilst the dependent variable employed was Profit after Tax. This study made use of secondary data obtained from the financial reports of five banks for a period of eleven (11) years (2005-2015) and primary data. Obtained secondary data were analysed using Regression analysis while Chi-square was used for secondary data. From the study based on the result of the analysis, it showed that corporate governance variables such as board directors have positive relationship on the performance of banks. However, the study established a negative relationship between profit after tax and board composition. The study supported the hypothesis that corporate governance positively affects performance of banks and recommended that awareness creation among banks operators should be conducted to ensure they have good knowledge of corporate governance and its implication on banks profit.
\end{abstract}

Keywords: corporate governance, bank performance, bank crisis

\section{Introduction}

Corporate governance is a crucial issue for the management of banks, which can be viewed from two dimensions. One is the transparency in the corporate function, thus protecting the investors' interest (reference to agency problem), while the other is concerned with having a sound risk management system in place (special reference to banks) (Jensen \& Macklin, 1976). The Basel Committee on Banking Supervision (1999) stated from a banking industry perspective that, corporate governance involves the manner in which the business and affairs of individual institutions are governed by their boards of directors and senior management thus affecting how banks set corporate objectives (including generating economic returns to owners); run the day-to-day

Babatunde Afolabi, Ph.D., senior lecturer, Department of Economics, Afe Babalola University, Ado Ekiti, Nigeria.

Awoyemi Olanike Bosede, Ph.D., Department of Economics, Afe Babalola University, Ado Ekiti, Nigeria.

Atsuwa Ruth, lecturer, Department of Banking and Finance, Afe Babalola University, Ado Ekiti, Nigeria.

Akomolafe John Kehinde, Ph.D, Department of Economics, Afe Babalola University, Ado Ekiti, Nigeria.

Correspondence concerning this article should be addressed to Afolabi Babatunde, Killometer 85 Afe Babalola Way, Afe Babalola University, PMB 5454, Ado Ekiti, Nigeria. 
operations of the business; consider the interest of recognized stakeholders; align corporate activities and behaviours with the expectation that banks will operate in safe and sound manner, and in compliance with applicable laws and regulations; and protect the interests of depositors.

The world becoming a global village with continuing speed in technology has made the financial sector more open to new products and services in the financial system. To ensure conformity with these changes, financial system operators strive to make available banking technological gadgets that will enhance operations in the system. Aside the above changes, the existence of consolidation has a far reaching effect on the banking systems. In line with these changes, there is a need for countries to have resilient banking system and strong corporate governance. However, lack of compliance with the laid down codes of corporate governance by the operators due to some mechanisms in the banking environment, has resulted in operational inefficiencies and gross misconduct both at the top management level and the lower management level.

Financial scandals around the world and the collapse of major corporate institutions in the USA (Enron and WorldCom which is associated with the U.S. federal government passing the Sarbanes-Oxley Act in 2002, intending to restore public confidence in corporate governance) and Europe have brought to the fore, once again, the need for the practice of good corporate governance, which is a system by which corporations are governed and controlled with a view to increasing shareholder's value and meeting the expectations of other stakeholders. Also, in developing economies, the banking sector among other sectors also witnessed several cases of collapse, some of which include the Savannah Bank PLC of Nigeria, the Continental Bank of Kenya Ltd and Consolidated Bank of Kenya Ltd (Akpan, 2007). Given the series of activities that have resulted due to non-compliance with the various consolidation policy requirements and the antecedent of disobedience to laws and regulation by some of the operators in the financial system, there are concerns on the need to strengthen corporate governance in banks.

In Nigeria, the issue of corporate governance has been given the front burner status by all sectors of the economy. For instance, the Securities and Exchange Commission (SEC) set up the Peterside Committee on corporate governance in public companies. The Bankers' Committee also set up a sub-committee on corporate governance for banks and other financial institutions in Nigeria. This is in recognition of the critical role of corporate governance in the success or failure of companies (Ogbechie, 2006) and the above actions will boost public confidence and ensure efficient and effective functioning of the banking system (Soludo, 2004).

Weak corporate governance in form of Board size and its composition, weak internal control systems and fraudulent practices among others remain a worrisome feature in the management of banking operations in Nigeria. Also, inadequate monitoring and supervision of financial institutions to ensure compliance with the provisions of the code of corporate governance precipitated the current Nigerian banking crisis.

Objectives of the study examine the various issues of operational strategies that constitute corporate governance challenges, bearing on the performance of Nigerian banks and how the consolidation exercise reduced bank crises but posed additional corporate governance challenges arising from integration process, information technology, and cultural harmonization.

\section{Literature Review}

Scholars from different parts of the world have different perspectives of what corporate governance in relation to banks performance and how its adequate implementation to reducing banks crises should be. However, what is more representative of the concept is the statement that "corporate governance refers to a set 
of rules and incentives by which the management of a company is directed and controlled" (Oso \& Semiu, 2012, pp.1-16). Corporate Governance as a concept advocates the constitution of a set of encoded laws, procedures and rules entrenched to guide the management of organisations for an equitable maintenance of balance in the practice and management of the rights and privileges of all stakeholders involved in the corporate organisation, including the supervisory roles, powers and privileges of the Board of Directors, management and staff, investors; (including the rights, roles and interests of monitory stakeholders), regulatory and governmental control organs toward effective performance and achievement of the objectives of the firm in the interest of all stakeholders and in compliance with acceptable international standards of practice (Linus, 2012).

According to Kajola (2012), corporate performance is an important concept that relates to the way and manner in which financial resources available to an organization are judiciously used to achieve the overall corporate objective of an organization. It keeps the organization in business and creates a greater prospect for future opportunities.

Furthermore, the Organization for Economic Cooperation and Development (OECD) in 1999 defined corporate governance principles as the system by which business corporations are directed and controlled. The pillars of good corporate governance have been known to shareholder rights, transparency and board accountability. Corporate governance is therefore, about building credibility, ensuring transparency and accountability as well as maintaining an effective channel of information disclosure that will foster good corporate performance.

Bank crises on the other hand exist due to asymmetric information giving rise to bank run and bank panic hence, withdrawal of deposit by customers and reduction in the performance of the bank due to inadequate capital or capital inadequacy.

\section{Corporate Governance Mechanisms}

Corporate governance mechanisms include a system of controls intended to help align managers' incentives with those of shareholders. According to Oman (2001), corporate governance mechanisms including accounting and auditing standards are designed to monitor managers and improve corporate transparency. Furthermore, a number of corporate governance mechanisms have been identified analytically and empirically. These, according to Agrawal and Knoeber (1996), may be broadly classified as internal and external mechanisms. Davis, Schoolman, and Donaldson (1997, p. 23) suggest that governance mechanisms "protect shareholders" interest, minimise agency costs and ensure agent-principal interest alignment”. They further opined that agency theory assumptions are based on delegation and control, which controls "minimise the potential abuse of the delegation”. This control function is primarily exercised by the board of directors on the internal/insider mechanisms of corporate governance as they relate to banking operations.

Oso and Semiu (2012) emphasize the importance of corporate governance of banks in developing economies and observe that: first, banks have an overwhelmingly dominant position in the financial system of a developing economy and are extremely important engines of economic growth; second, with underdeveloped financial markets, banks in developing economies are typically the most important source of finance for majority of firms; third, as well as providing a generally accepted means of payment, banks in developing countries are usually the main depository for the economy's savings.

Banking supervision cannot function if what Hettes (2002) called "correct corporate governance" does not exist. Hettes explained further by observing that correct corporate governance simplifies the work of banking 
supervision and contributes towards corporation between the management of a bank and the banking supervision authority.

Donald (2001, p. 2) observed that "improving corporate governance is an important way to promote financial stability and the effectiveness of a bank's internal governance arrangements has a very substantial effect on the ability of a bank to identify, monitor and control its risks".

Although banking crises are caused by many factors, some of which are beyond the control of bank management, almost every bank failure is at least partially as a result of mis-management within the bank itself. Ultimately, banking risks are most likely to be reduced to acceptable levels by fostering sound risk management practices within individual banks and encouraging sound corporate governance practice within banks is a crucial element of achieving this (Jensen, 2001).

Carse (2000, p. 2) observed that:

corporate governance is of course not just important for banks. It is something that needs to be addressed in relation to all companies, sound corporate governance is particularly important for banks because, the rapid changes brought about by globalization, deregulation and technological advances are increasing the risks in banking systems.

\section{Theoretical Review}

Stakeholder's Theory. It stipulates that a corporate entity finds procedures or means of ensuring that the interest of the shareholders or stakeholders is kept in the balance with those of the bank. However, there is an argument that the theory is narrow (Coleman \& Nicholas, 2006) because it identifies the shareholders as the only interest group of a corporate entity whereas they are other factors like those interested in the affairs of such an organisation. One of the original advocates of stakeholder theory, (Freeman, 1984), identified the emergence of stakeholder groups as important elements to the organization requiring consideration. This theory focuses on the issues of stakeholders in an institution. Under stakeholder theory, it is believed that managers have a multiplicity of objective functions to optimize, something that Jensen sees as an important weakness of the stakeholder theory "because it violates the proposition that a single-valued objective is a prerequisite for purposeful or rational behaviour by any organisation” (Jensen \& Meckling, 1976, p. 305).

Stewardship Theory. This theory links the success of firms with that of the managers. It tends to argue against the agency theory which says that managerial opportunism is not relevant. This theory stipulates that a manager's objective is first to maximise the firm's value because, a manager's need of achievement and success is met when the firm is doing well (Coleman \& Nicholas, 2006). This theory addresses the issue of trust which the agency theory refers with respect for authority and inclination to ethical behaviour. A fall out of this theory is that, it attacks the areas of board of directors and leadership issues in a firm. Under the board of directors, it is believed that the involvement of the non-executive directors is important in enhancing the board activities. Under leadership, this theory is contrary to that of the agency theory. Stewardship theory supports the idea that Chief Executive Officer and board chair should be the same individual to ensure that decisions are quickly and promptly taken which will surely have impact on the firm. Finally, this theory stipulates that small board sizes should be encouraged to enhance effective communication and decision making. Nevertheless, the theory does not stipulate how an optimal board size should be determined.

Agency Theory. The agency theory has its roots in economic theory and it dominates the corporate governance literature. Daily, Dalton, and Canella (2003), point to two factors that influence the prominence of agency theory. First, the theory is a conceptually simple one that reduces the corporation to two participants, 
managers and shareholders. Second, the notion of human beings as self-interested is a generally accepted idea.

In its simplest form, agency theory explains the agency problems arising from the separation of ownership and control. It "provides a useful way of explaining relationships where the parties' interests are at odds and can be brought more into alignment through proper monitoring and a well-planned compensation system” (Davis, Schoorman, \& Donaldson, 1997, p. 24). In her assessment and review of agency theory, Abubarka (2011) outlines two streams of agency theory that have developed over time: principal-agent and positivist. Principal-agent research is concerned with a general theory of the principal-agent relationship, a theory that can be applied to any agency relationship while a positivist perspective focus on identifying circumstances in which the principal and agent are likely to have conflicting goals and then describe the governance mechanisms that limit the agent's self-serving behaviour (Abubarka, 2011).

The fundamental problem of this theory is how the managers follow the interest of the shareholders to ensure that agency cost is reduced. Also, the principals are confronted with how to select the most capable manager and how to ensure that managers are given the right incentive to take decisions that are aligned with shareholders' interest.

\section{Methodology}

The data used for this study were extracted from Nigerian Stock Exchange Fact Book and administered questionnaire capturing corporate governance monitoring and supervision. The interest rate policy reform is captured by a dummy variable (0-regulated interest rate and 1-deregulated interest rate policy), while the board composition and size from annual reports of banks and CBN bulletins.

The study employs a modified version of the econometric model of Miyajima, Omi, and Saito (2003) as adopted by Coleman and Nicholas-N (2006) with little modifications. The Econometric model of Miyajima et al. (2003) is therefore seen below as:

$$
\mathrm{Y}_{\mathrm{it}}=\beta_{\mathrm{o}}+\beta_{1} \mathrm{G}_{\mathrm{it}}+\beta_{2} \operatorname{IntrRf}_{\mathrm{t}}+\beta_{3} \mathrm{SIZE}_{\mathrm{t}}+\beta_{4} \mathrm{BCOM}_{\mathrm{t}}+\mathrm{e}_{\mathrm{t}}
$$

where,

$\mathrm{Y}_{\mathrm{it}}$ represents firm performance variables which are earnings per share for banking firms at time $t$;

$\beta_{0}$ represents the constant factor;

$\mathrm{G}_{\text {it }}$ is a vector of corporate governance variables which include: Board Size (BSIZE), Board Composition (BCOM) which is defined as the ratio of outside directors to total number of directors;

intrdum is interest rate policy;

SIZE $_{\mathrm{t}}$ is the size of the firm;

$\mathrm{BCOM}_{\mathrm{t}}$ is board composition of the firm;

$\beta 1-\beta 4$ represent parameter coefficients of the model;

$e_{t}$ is the error term which accounts for other possible factors that could influence the independent variable.

Based on the fact that different governance and performance proxies were employed, the above model is therefore modified to determine the relationship between bank performance and corporate governance of banks in Nigeria.

The apriori is such that:

$\beta_{1}$ BOS $_{t} ; \beta_{2}$ BCOMP $_{t}>0$. The implication of this is that a positive relationship is expected between explanatory variable $\left(\beta_{1} \mathrm{BOS}_{\mathrm{t}} ; \beta_{2} \mathrm{BCOMP}_{\mathrm{t}}\right)$ and the dependent variable profit after tax (PAT). The size of the coefficient of correlation will help explain various levels of relationship between the explanatory variables. 
Where:

PAT represents banks performance variable which is: profit after tax for banking firms at time $t$ which will be based on the secondary data obtained from the annual report of all sampled banks;

BOS represents the Board Size; Board Composition is represented by BCOMP which is defined as the ratio of outside directors to total number of directors;

$e_{t}$ is the error term which accounts for other possible factors that could influence PAT which is not captured in the model.

\section{Regression Analysis}

Table 1

Model Summary

\begin{tabular}{lllll}
\hline Model & $\mathrm{R}$ & $\mathrm{R}$ square & Adjusted R square & Std. error of the estimate \\
\hline 1 & $0.220^{\mathrm{a}}$ & 0.048 & -0.003 & 110.80718 \\
\hline
\end{tabular}

a. Predictors: (Constant), Board Composition, Board Size.

Regression coefficient was used to test if there is any significant relationship between earnings per share (criterion/dependent variables) and board of Directors (predictor/independent variables). The ordinary least square regression analysis was used. The result from the analysis shows that a low relationship exists between board of directors and earnings per share. This is depicted by the $\mathrm{R}$ value of 0.97 . The coefficient of determination $\left(\mathrm{R}^{2}\right)$ is 0.048 which shows that only $4.9 \%$ percent of the variations in the performance of banks selected were explained by the independent variable.

Table 2

ANOVA $^{b}$

\begin{tabular}{lllllll}
\hline Model & & Sum of squares & df & Mean square & F & Sig. \\
\hline \multirow{2}{*}{1} & Regression & $23,007.758$ & 2 & $11,503.879$ & 0.937 & $0.401^{\text {a }}$ \\
& Residual & $454,294.582$ & 37 & $12,278.232$ & & \\
& Total & $477,302.339$ & 39 & & & \\
\hline
\end{tabular}

a. Predictors: (Constant), Board Composition, Board Size.

b. Dependent Variable: Profit After Tax.

From the above table, the significant value ( $p$ value) is 0.401 , which shows that the regression model derived could not be relied upon for prediction over and above 99\% confidence level. However, using 5\% level of significance (alpha $\alpha$ ) and since alpha is less than $p$ value (table above 0.401 ) we conclude that the board size and composition has positive weak effect on the banks performance. The $p$ value (0.401) above the level of significance $(\alpha)$ indicates that the model fails to explain a lot of variations in PAT.

Table 3

Coefficients

\begin{tabular}{|c|c|c|c|c|c|c|}
\hline \multirow{2}{*}{ Model } & & \multicolumn{2}{|c|}{ Unstandardized coefficients } & \multirow{2}{*}{$\begin{array}{l}\text { Standardized coefficients } \\
\text { Beta }\end{array}$} & \multirow{2}{*}{$\mathrm{T}$} & \multirow{2}{*}{ Sig. } \\
\hline & & $\mathrm{B}$ & Std. error & & & \\
\hline \multirow{3}{*}{1} & (Constant) & -27.562 & 86.618 & & -0.318 & 0.752 \\
\hline & Board size & 7.400 & 5.782 & 0.206 & 1.280 & 0.209 \\
\hline & Board composition & -19.936 & 33.572 & -0.096 & -0.594 & 0.556 \\
\hline
\end{tabular}


From the table above, the sig. value is 0.209 and 0.556 for BSIZE and BCOM respectively which shows that board size and board composition of bank has positive weak relationship on banks performance (EPS). A change in board size will bring change in EPS by 7.4 while composition is -19.936.

Regression Equation i.e. $\mathrm{Y}=\alpha+\mathrm{B}_{1} \mathrm{x}_{1}+\mathrm{B}_{1} \mathrm{X}_{2}$

$$
\mathrm{Y}=-19.936-27.562 \mathrm{X}_{1}+7.400 \mathrm{X}_{2}
$$

Therefore, a change of 1 in $x$ (i.e. BOARD SIZE and BOARD COMPOSITION) means a change of $7.4 \mathrm{X}_{1}$ and $-19.936 \mathrm{X}_{2}$ in $\mathrm{Y}$ (i.e. PROFIT AFTER TAX).

Also, $\mathrm{R}^{2}=0.048$.

It shows that $\mathrm{Y}$ can explain about $4.8 \%$ of the variations in independent variable $\mathrm{X}$ and $\mathrm{R}=0.22$ which shows that there is a positive weak relationship between board size, board composition, and profit after tax.

Table 4

Chi-square Tests

\begin{tabular}{llll}
\hline & Value & Df & Asymp. sig. (2-sided) \\
\hline Pearson chi-square & $108.709^{\mathrm{a}}$ & 4 & 0.000 \\
Likelihood ratio & 38.947 & 4 & 0.037 \\
Linear-by-Linear association & 2.734 & 1 & 0.098 \\
N of valid cases & 84 & & \\
\hline
\end{tabular}

0 cells $(0.0 \%)$ have expected frequencies less than 5 . The minimum expected cell frequency is 61.2 .

From the result shown in Table 4, where Xcalc $=108.709, \mathrm{Xtab}=0.98$, degree of freedom $\mathrm{df}=4 \mathrm{It}$ clearly shows that the calculated value of Chi-square is greater than the tabulated value, which means that poor corporate culture precipitated the current banking sector crisis.

\section{Summary, Conclusion and Recommendations}

From the study based on the result of the analysis, it showed that corporate governance variables such as board of directors have positive relationship on the performance of banks. However, the study established a negative relationship between profit after tax and board composition. The board composition shows a negative relationship with the profit after tax which means there is a decrease in the performance of the banks whenever there is an increase in the number of independent directors on the list of board of directors. The board size shows a positive relationship with profit after tax which means that there is an increase in the performance of the bank when the board size is at its peak and increase in the performance of bank will increase the level of their service delivery to customers.

The survival and stability of any financial sector depends on the quality of its governance. In spite of several reforms put to strengthen this sector, banks were still prone to failure. The loss associated with this failure is enormous on their reputation and industrial growth. Hence, strong governance framework to enhance compliance to corporate governance codes becomes imperative. Corporate governance is considered to involve a set of complex indicators, which face substantial measurement error due to the complex nature of the interaction between governance variables (such as board size, board composition, etc.) and firm performance indicators. Nevertheless, previous empirical studies (Ahmad \& Tukur, 2005; Akpan, 2007) have provided the link between corporate governance and firm performance. However, despite the volume of the empirical work, there is no consensus on the impact of corporate governance on bank performance. Consequently, this lack of 
consensus has produced a variety of ideas (or mechanisms) on how corporate governance influences bank performance.

However, this study examines the relationship between corporate governance on banks' performance and crises in Nigeria between 2005 and 2015. The study has been able to show that the Nigerian banking sector is affected by the level of corporate governance culture being embraced. Two board classes were used, namely board composition and board size. Regression analysis was done against profit after tax based on the secondary data obtained from the annual report of banks.

From the findings of the study, the following recommendations are suggested:

(1) The board size of banks in Nigeria should not be too large (since it is part of the code of corporate governance requirement by both CBN and NDIC) and must be made up of qualified professional who are conversant with oversight function and the issue of transparency, accountability and disclosure by banks should be taken more seriously.

(2) Most of the operators in banks have little or no knowledge of corporate governance; this was discovered during the researcher's data sourcing period. Hence, awareness creation among banks should be conducted to ensure compliance with code of corporate governance.

(3) Uniformity in the code of corporate governance in the system should be encouraged to ensure single reporting authority and a unified corporate body saddled with the responsibility of collecting and collating corporate governance related data and constructing the relevant indices to facilitate corporate governance research in Nigeria should be set up.

(4) Finally, In order to address failures of corporate governance in the industry, the CBN should establish a specialist function focusing on governance issues to ensure governance best practices are embedded in the industry also, the reform programme should be able to strengthen corporate governance in both banks and financial institutions and they should have an embedding culture across the industry that good governance is good business.

\section{References}

Abubarka, S. (2011). Agency problem in corporate governance in Nigerian banking industry. Journal of Banking and Finance, 22, 371-403.

Ahmad, S. A., \& Tukur, G. (2005). Corporate governance mechanism and firms' financial performance in Nigeria. Research paper 149. African Economic Consortium. Nairobi, Kenya.

Akpan, E. S. (2007). Does corporate governance affect bank profitability? Evidence from Nigeria. American International Journal of Contemporary Research, 2(7).

Agrawal, A., \& Knoeber, C. R. (1996). Firms performance and mechanisms to control agency problems between managers and shareholders. The Journal of Financial and Quantitative Analysis, 31(3), 377-397.

Carse, D. (2002). Speech on the importance of corporate governance in banks. Retrieved May 2011. Website: http//www.infor.gov.hk/hkma/eng/speeches

Coleman, A., \& Nicholas, N. (2006). Does board and CEO matter for bank performance? A comparative analysis of banks in Ghana. Journal of Business Management, 13, 46-59.

Daily, M. D., Dalton, D. R., \& Cannella, A. A. (2003). Corporate governance: Decades of dialogue and data. Academy of Management Review, 28(3), 371-382.

Davis, J., Schoorman, F., \& Donaldson, L. (1997). Towards a stewardship theory of management. Academy of Management Review, 22(1), 20-47.

Donald, T.B. (2001). Promoting Financial Stability: The New Zealand Approach. An Address by Dr Donald T Brash, Governor of the Reserve Bank of New Zealand, to the conference for Common Wealth Central Banks on Corporate Governance for the Banking Sector, London, 6 June 2001. 
Freeman, E. (1984). Divergent stakeholder theory. Academy of Management Review, 24, 233-239.

Hettes, F. (2002). Corporate governance in the banking act: National bank of Slovakia. BIATEC, 5, 42-60.

Jensen, M., \& Meckling, H. (1976). Theory of the firm: Managerial behaviour agency cost and ownership structure. Journal of Financial Economics.

Jensen, M. C. (2001). Value maximization, stakeholder theory, and the corporate objective function. Working Paper No. 01-01, Harvard Business School.

Kajola, S. O. (2012). Corporate governance and firm performance: The case of Nigerian listed firms. European Journal of Economics, Finance and Administrative Sciences, 14, 16-28.

Lai, O., \& Semiu, B. (2012). The concept and practice of corporate governance in Nigeria: The need for public relations and effective corporate communication.

Linus. (2012). Corporate governance and financial performance of banks. The Nigerian Economic Summit Group (NSESC).

Miyajima, H., Omi, Y., \& Saito, N. (2003). Corporate governance and performance in twentieth century Japan. Business and Economic History, 1, 1-35.

Ogbechie, C. (2006). Corporate governance and board practices in Nigerian banking industry. International Journal of Financial Economics.

Oman, C. P. (2001). Corporate governance \& natural development. An outgrowth of the OECD Development Centres Experts Workshop in 2000 and Informal Policy Dialogue in 2001 Sponsored in part by CIPE.

Oso, L., \& Semiu, B. (2012). The concept and practice of corporate governance in Nigeria: The need for public relations and effective corporate communication, 3(1), 1-16.

Soludo, C. C. (2004). Consolidating the Nigerian banking industry to meet the development challenges of the 21st century. Being an address to the Special Meeting of Bankers Committee, held on July 6. 